\title{
A Case of Autoimmune Sensorineural Hearing Loss Responding to Cytotoxic Agent
}

\author{
Yong Woo Lee, Jin Lee, Min-Beom Kim ${ }^{\mathbb{D}}$, and Sun O Chang ${ }^{\mathbb{D}}$ \\ Department of Otolaryngology-Head and Neck Surgery, Kangbuk Samsung Hospital, Sungkyunkwan University School of Medicine, \\ Seoul, Korea
}

\author{
세포독성약제에 반응한 자가면역성 감각신경성 난청 1예 \\ 이용우 · 이 진 · 김민범 · 장선오 \\ 성균관대학교 의과대학 강북삼성병원 이비인후과학교실
}

\author{
Received July 31,2018 \\ Revised September 20, 2018 \\ Accepted October 2, 2018 \\ Address for correspondence \\ Min-Beom Kim, MD, PhD \\ Department of Otolaryngology- \\ Head and Neck Surgery, \\ Kangbuk Samsung Hospital, \\ Sungkyunkwan University \\ School of Medicine, \\ 29 Saemunan-ro, Jongno-gu, \\ Seoul 03181, Korea \\ Tel +82-2-2001-2264 \\ Fax $+82-2-2001-2273$ \\ E-mail minbeom.kim@gmail.com
}

Autoimmune sensorineural hearing loss is a rare disease characterized by bilateral sensorineural hearing loss, some in a progressive pattern and others in idiopathic or fluctuating pattern, often accompanied by vestibular symptoms. This disease is also known as autoimmune inner ear disease (AIED), which primarily involves the vestibulo-cochlear system. However, in some cases, it occurs in the context of systemic autoimmune disorder such as wegner granulomatosis, or the Bechet disease. Response to steroids has been the requisite clinical criterion for diagnosis. Treatment usually includes corticosteroids and immunosuppressive drugs. However, after continuous steroid treatment development of corticosteroids, resistance is common in many AIED. To patients with AIED, response to steroids is not only a criterion for diagnosis but also a criterion to test steroid-sparing therapies such as methotrexate. A 10 year-old boy presenting a fluctuating pattern of bilateral sensorineural hearing loss was treated with a cytotoxic agent in suspicion of autoimmune sensorineural hearing loss. We reviewed this case with reference to relevant publications in the medical literature.

Korean J Otorhinolaryngol-Head Neck Surg 2019;62(8):470-4

Key Words Autoimmune sensorineural hearing loss $\cdot$ Cytotoxins $\cdot$ Methotrexate.

\section{서 론}

자가면역성 내이질환(autoimmune inner ear disease, AIED) 으로도 알려진 자가면역성 감각신경성 난청은 1940년대에 Cogan에 의해 처음 기술되면서 알려진 질환이다. ${ }^{1 .}$ 이후, 1970 년대에 소수의 환자들을 대상으로 스테로이드와 cyclophosphamide의 병합요법을 사용하여 효과를 보았다는 것이 McCabe에 의해 보고되었다.') 이 질환은 전정와우 신경의 기능이 상으로 기인하는 것으로 알려져 있으며, ${ }^{3)}$ 최소 일측에서 3일 이상, 90 일 이내의 기간에 걸쳐서 진행하거나 변동성을 보이
는 양측성 감각신경성 난청이 나타나는 것으로 보고되고 있 다. ${ }^{4.5)}$ 임상 양상에 덧붙여서 스테로이드를 포함한 면역억제제 에 반응 여부가 진단에서 중요한 기준으로 여겨지며, 면역학 적검사에의 양성 여부도 진단에 도움을 주며 다른 가능한 내 이질환과의 감별이 필요하다.) 본 저자들은 단기간에 진행한 양측성 청력 저하를 주소로 내원하여, 고용량 스테로이드 요 법에 반응하였으나, 치료 이후에도 반복적인 변동성 감각신경 성 난청을 보인 10 세 남아를 치험하였다. 이에 자가면역성 감 각신경성 난청으로 진단하여 세포독성제제를 사용하여 치료 하였기에 문헌고찰과 함께 보고하는 바이다.

This is an Open Access article distributed under the terms of the Creative Commons Attribution Non-Commercial License (https://creativecommons.org/licenses/by-nc/4.0) which permits unrestricted non-commercial use, distribution, and reproduction in any medium, provided the original work is properly cited. 


\section{증 례}

10세 남아가 수일 전에 급작스럽게 발생한 양측 귀의 청력 저하를 주소로 내원하였다. 과거력과 가족력상 특이사항은 없었고, 난청 이외에 현훈과 안통증 및 시력이상, 그 외 신경학 적 증상은 호소하지 않았다. 이학적검사상 고막 소견은 정상 이었고 안구충혈은 없었으며, 비디오안진검사상 안진은 관찰 되지 않았다. 시력검사를 포함한 뇌신경검사, 소뇌기능검사 를 비롯하여 운동과 감각기능상에서도 이상 소견은 보이지 않았다. 병력과 이학적검사상 다른 계통의 이상은 관찰되지 않았기에 추가적으로 안과나 신경과적인 정밀검진을 시행하 지는 않았다. 처음 내원하여 시행한 순음청력검사상 양측 모 든 음역에 걸친 평면 형태의 고도 감각신경성 난청 소견을 보 였고(Fig. 1A), 당시 환아의 체중은 $49 \mathrm{~kg}$ 로 입원하여 10일 간 하루 $48 \mathrm{mg}$ 의 methylprednisolone 경구 투여 치료와 함
께 비디오 두부충동검사, 청성뇌간 반응검사와 측두골 전산 화단층촬영 및 자기공명영상(MRI) 등의 추가 검사를 시행했 다. 입원 시 시행한 혈청학적검사상 매독혈청검사와 Human Immunodeficiency Virus 항체는 음성으로 확인되었고, 비 디오 두부충동검사상 전정안반사(vestibular-ocular reflex) 는 정상이었다. 청성뇌간 반응검사에서는 우측은 $90 \mathrm{~dB}$, 좌 측은 $80 \mathrm{~dB}$ 에서 $\mathrm{V}$ 파형이 확인되었으며, 양측 latency에 delay는 관찰되지 않았다. 또한, 측두골 전산화단층촬영상에 서 해부학적 이상은 확인되지 않았으며, 자기공명영상에서 내이수종(endolymphatic hydrops)과 후미로상의 병변은 확 인되지 않았다(Fig. 2). 환아는 치료 4일째, 순음청력검사에 서 부분적인 청력역치의 호전을 보여 퇴원하였으나, 치료 8 일 째, 청력검사상 양측 역치가 $60 \mathrm{~dB}$ 정도로 확인되고 환아도 여전히 당시의 청력에 불편감을 호소하여, 스테로이드 경구 투여 하는 것을 2주기를 추가로 시행하였고, 추가적인 청력역

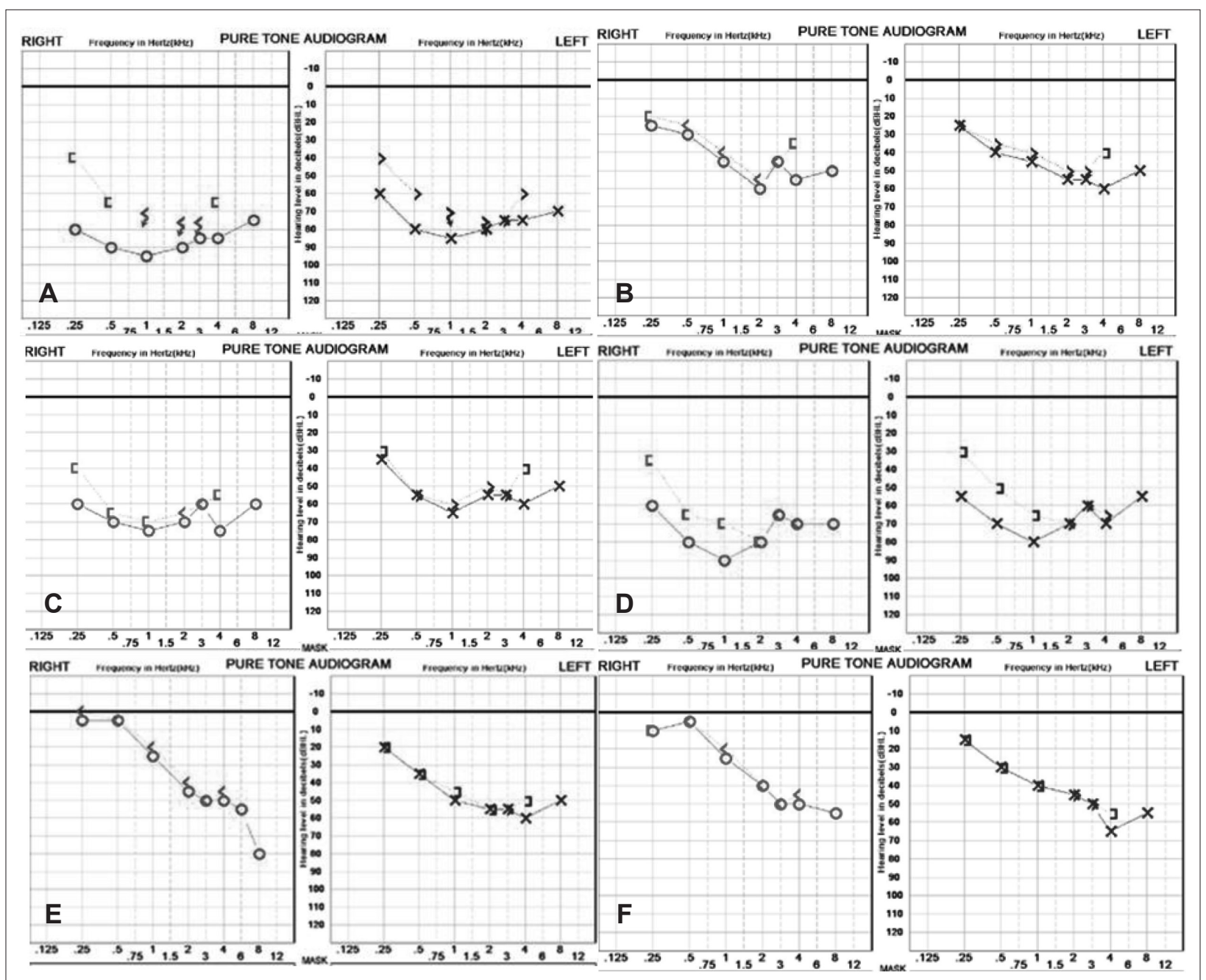

Fig. 1. Flow of audiogram at each attack and methotrexate therapy. Audiogram on initial presentation (A), audiogram after a month of steroid therapy (B), audiogram at the time of 2 nd attack of hearing loss (C), audiogram at the time of 3rd attack of hearing loss (D), audiogram at the time initiating cytotoxic therapy $(E)$, and audiogram after 6 month of methotrexate administration $(F)$. 
치의 호전이 있었다(Fig. 1B). 이후, 스테로이드 복용을 중단 하고 경과 관찰을 계획하였으나 약 복용을 중단한지 10여 일 이 지나 2차적으로 주관적인 청력저하와 함께 청력역치의 악 화가 확인되었고, 스테로이드 요법을 같은 약제로 용량을 반 으로 줄여 $24 \mathrm{mg} / \mathrm{day}$ 로 7일간 시행 후 3일에 걸쳐 tapering 하게 되었다(Fig. 1C). 스테로이드 복용 후 청력역치는 2차 난 청이 발생하기 이전 수준으로 회복되어, 스테로이드의 부작 용을 감안하여 청력을 유지되는 최소용량을 찾기 위해 약제 를 $16 \mathrm{mg}$ 을 격일로(every other day, EOD) 사용하는 저용량 지속요법으로 전환하였다. 하지만, 용량을 줄이고 3주가량 경과한 시점에서 환자는 다시금 청력저하를 호소하며 검사 에서도 역치가 악화되어 3차 난청이 발생했음을 확인할 수 있었다(Fig. 1D). 따라서 감량하였던 스테로이드를 증량하여 $48 \mathrm{mg} / \mathrm{day}$ 로 4일간, $32 \mathrm{mg} / \mathrm{day}$ 로 3일간 사용하였고, 청력역
치는 3차 난청 이전 수준으로 회복되었다. 그 이후로는 동일 한 약제를 $32 \mathrm{mg}$ 을 격일로(EOD) 사용하며 지속요법을 시행 하였다.

반복적으로 단기간에 진행하는 양측성 난청의 발생과 스테 로이드 치료에 단기간에 회복하는 것을 반복하였으나, 전정 증상을 비롯하여 다른 계통의 이상은 없었으며 혈청학적 및 영상검사상 다른 내이질환의 증거를 관찰할 수 없어, 자가면 역성 감각신경성 난청을 의심하게 되었고, 3 차 난청이 발생한 시점에서 면역학적검사로 항이중가닥 DNA 항체(anti-dsDNA $\mathrm{Ab}$ ), 류마티스 인자(RA factor), 항핵항체(antinuclear antibody), Anti-Ro 항체, Anti-La 항체 검사를 시행하였으나 음 성 반응을 보였고, 보체 C3과 $\mathrm{C} 4$ 수치는 정상 범위 내에 있었 다. 반복적인 난청으로 환아는 이미 4개월 이상 스테로이드를 투여받고 있었고, 약제를 중단할 수 없어 steroid sparing agent

Fig. 2. Inner ear MRI. No endolymphatic hydrops on T2 weighted image $(A)$. T1 weighted image shows no retro-cochlear lesion (B).
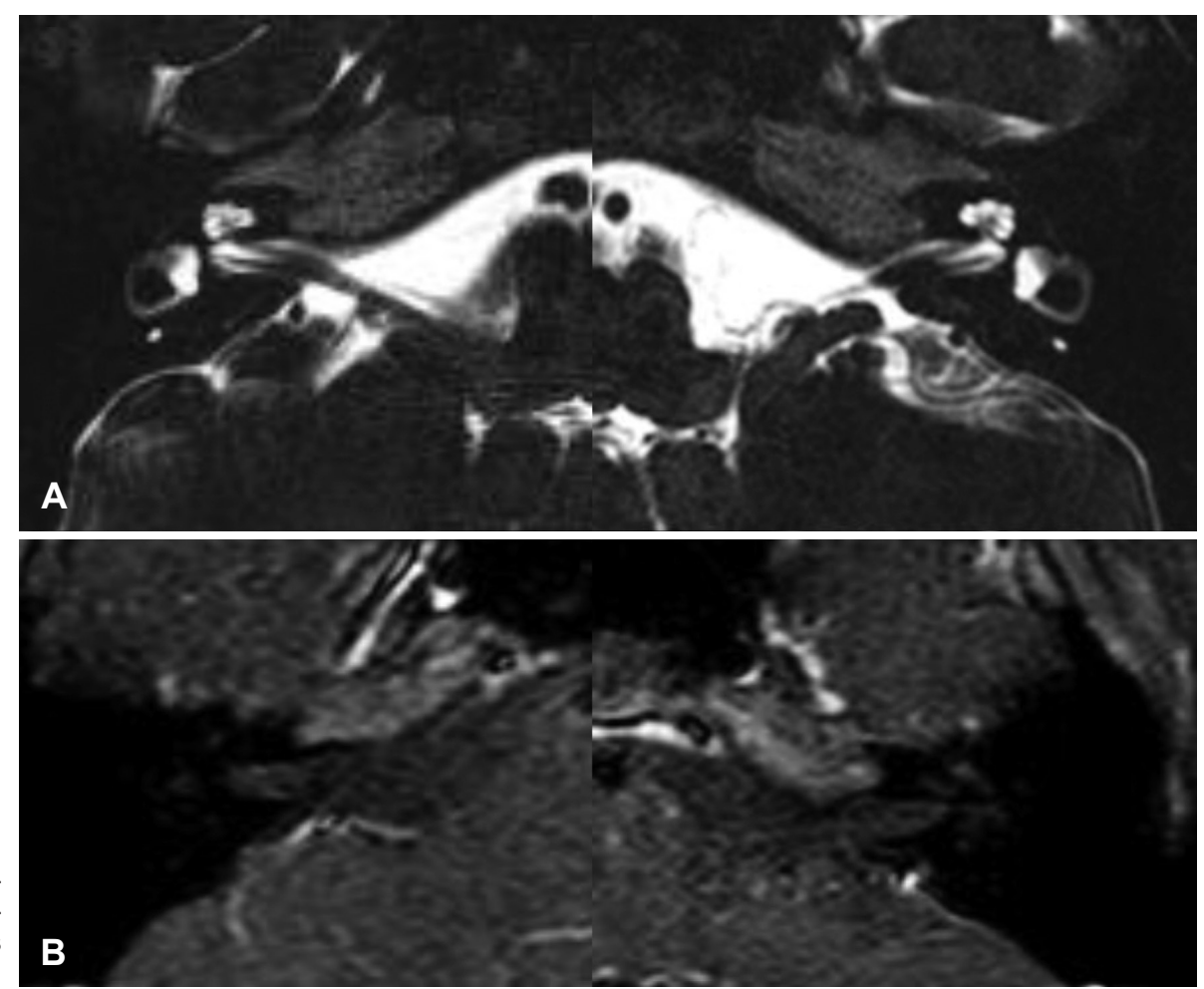

Table 1. Flow of hearing level at each attack and MTX therapy

\begin{tabular}{lcccc}
\hline & $\begin{array}{c}\text { Pure tone } \\
\text { average (right) }\end{array}$ & $\begin{array}{c}\text { Pure tone } \\
\text { average (left) }\end{array}$ & $\begin{array}{c}\text { Word recognition } \\
\text { score (right) }\end{array}$ & $\begin{array}{c}\text { Word recognition } \\
\text { score (left) }\end{array}$ \\
\hline Initial presentation & 90.8 & 80.8 & 16 & 48 \\
After 1 month steroid therapy & 49.2 & 50.0 & 80 & 84 \\
2nd attack of hearing loss & 72.5 & 59.2 & 48 & 56 \\
3rd attack of hearing loss & 81.7 & 73.3 & 12 & 48 \\
MTX initiation & 32.5 & 50.8 & 88 & 80 \\
After 6 month MTX therapy & 30.8 & 44.2 & 88 & 76 \\
\hline
\end{tabular}

MTX: methotrexate 
사용을 고려하게 되었다. 환아는 methotrexate(MTX)를 한 주에 $10 \mathrm{mg}$ 씩 경구 복용하면서 steroid sparing을 시작하였고 (Fig. 1E), 이후 6개월간 MTX를 복용하면서 추가적인 난청 발생 없이 청력이 관해된 상태를 유지하였다(Fig. 1F). 청력 의 추가적인 악화는 없었지만 일상생활에 다소 불편함을 느 껴, 청력이 좀 더 좋지 않은 좌측에 RIC type 보청기를 처방 받아 사용 중에 있으며 향후 MTX를 중단하고 경과관찰 예 정이다(Table 1).

\section{고 찰}

자가면역성 감각신경성 난청은 전체 난청 환자 중, $1 \%$ 미만 을 차지하는 드문 질환으로, 면역매개성(immune-mediated) 내이질환의 발생기전은 선천면역과 획득면역체계를 모두 포 함하는 것으로 내프림낭(endolymphatic sac)에 면역반응을 발생시킨다.7) 이러한 반응은 최종적으로 와우 내의 감각세포 와 지지세포들을 파괴하는 결과로 연결되며, interleukin-1 (IL-1), IL-2와 tumor necrosis factor-alpha(TNF- $\alpha$ )와 같 은 사이토카인(cytokine)과 nuclear factor-kB와 같은 전사 인자(transcription factor)가 이 질환의 면역반응에 관련되어 있다.,8) 90 년대 중반에 AIED에서 면역반응을 야기하는 68 $\mathrm{kD}$ 의 크기를 가지는 단백질이 heat shock protein 70 (HSP70)의 항체로 작용하며, 이 단백질이 스테로이드 반응성에 대 한 예측인자로 생각되었다.") 하지만 후속 연구에서 AIED의 9\%에서만 HSP-70이 확인되고, 대조군과 의미 있는 차이가 관 찰되지 않아 진단에서의 효용성이 떨어지는 것으로 확인되었 다.,10) 그 외에도 anti-cochlin과 같은 자가항체가 소규모 코 호트 연구에서 보고되고 있으나, 현재까지 AIED에 특이한 것 으로 밝혀진 항체는 없다. ${ }^{11,12)}$ 따라서 다른 전신적인 면역학적 질환이 동반되지 않은 경우에 이 질환을 진단하는 것은 더욱 쉽지 않은 일이다. ${ }^{1,13}$ 임상 양상과 다른 내이 질환에 대한 배 제적 진단이 다른 전신적 자가면역질환이 없는 AIED 환자 의 진단에 중요한 부분이나, ${ }^{14}$ 환자의 $20 \%$ 에서는 메니에르병 (Ménière's disease, MD)과 유사한 양상의 현훈을 호소한다 고 알려져 있다.") $\mathrm{AIED}$ 의 임상 양상은 많은 부분에서 $\mathrm{MD}$ 와 유사하여, 처음 한 달 사이에는 두 질환 사이의 감별이 어 렵다. 하지만 시간이 경과함에 따라 $\mathrm{MD}$ 에 비하여 더욱 공격 적인 경과를 보여, ${ }^{13)}$ 기간을 두고 반복적으로 청력검사를 시행 하는 것이 진단을 확인하는데 필요하다.

만일 환자가 양측의 변동성 감각신경성 난청을 보이고, 이를 설명할 만한 원인을 찾기 힘들 경우에는 자가면역성 감각신 경성 난청을 고려해야 하며 다른 전신적인 자가면역성질환 여부를 면역학적검사를 통하여 확인하여야 할 것으로 사료
된다. 하지만, 이러한 검사 결과들은 1 차성 자가면역성 난청 의 진단과는 연관성이 떨어진다는 점을 알아야 하며 기존 문 헌에서도 $30 \%$ 내외에서만 다른 자가면역질환이 동반되는 것 으로 보고되고 있다. ${ }^{5,15,16)}$ 또한, 내이수종과 후미로성 병변을 확인하기 위하여 MRI 검사도 반드시 시행해야 한다. 자가면역 성 감각신경성 난청의 주된 치료는 스테로이드로, prednisone 기준으로 $1 \mathrm{mg} / \mathrm{kg} / \mathrm{day}$, methylprednisolone 기준으로 $0.8 \mathrm{mg} /$ $\mathrm{kg} / \mathrm{day}$ 의 용량으로 최소 28 일을 사용하는 것으로 알려져 있 고, 치료에 반응을 보이면 감량하여 유지용량을 장기간 지속 하는 요법이 권장되고 있다.,16,17) 질환이 재발하는 경우에는 동일한 요법으로 치료를 반복할 수 있으나, 약물을 감량하면 서 반복적으로 악화되는 임상 양상을 보일 시에는 치료에 어 려움을 겪게 된다. ${ }^{7}$ 뿐만 아니라, 기존 문헌에서 스테로이드 에 반응하는 환자들도 반복적인 청력의 감퇴가 있는 경우에 34 개월의 시간이 지난 이후에는 대다수가 스테로이드 불응성 으로 전환되는 자연경과를 보이고, ${ }^{18)}$ 다른 자가면역질환에서 도 이러한 자연경과가 흔하게 나타나는 것으로 보고되고 있 다. ${ }^{19,20)}$ 이러한 환자들에서 비가역적으로 고도 이상의 난청이 발생하면, 인공와우 이식술을 주저 없이 시행할 것을 권장하 고 있다. ${ }^{13)}$ 기존에 스테로이드에 반응을 보이지 않을 경우에 cyclophosphamide, MTX, anti-TNF- $\alpha$ 제제(adalimumab, etanercept) 등을 사용하는 것으로 알려져 있지만, ${ }^{3)}$ 스테로이 드에 반응을 하는 환자에서도 자가면역질환의 자연경과를 고 려하면 임상적으로 MTX나 etanercept 등을 steroid-sparing agent로 시도해 볼 수 있는 근거가 된다.) 최근에는 20명의 자 가면역성 감각신경성 난청환자에서 세포독성제제인 azathioprine을 $1.5 \sim 2.5 \mathrm{mg} / \mathrm{kg} / \mathrm{day}$ 의 용량으로 사용하여 청력 유지 에 효과가 있었다는 것이 보고되기도 하였다. ${ }^{21)}$

본 환자는 스테로이드 감량 시에 반복적으로 청력역치가 악 화되어 steroid-sparing agent를 통해 증상 조절을 시도하였다. 이러한 약제로 흔히 언급되는 것이 cyclophosphamide로 자가 면역질환의 조절에 효과적이라고 알려져 있지만, 골수 억제, 불임, 발암 등의 위험성도 공존한다.) 따라서, 세포독성제제 를 사용하기 전에 약제의 부작용 및 합병증을 충분히 설명하 여야 하며, 사용 중에도 독성 반응에 대한 면밀한 관찰이 필요 하다. 환자가 기저질환이 없는 10 세 남아라는 점을 고려하여 비 교적 독성이 적은 제제인 MTX를 선택하였다. 환아는 6개월 의 약제 복용 기간 동안 이상 반응을 호소하지 않았고, 혈액검 사상에서도 이상 소견은 관찰되지 않았다. 저자들은 면역학 적 및 혈청학적 검사상 음성 반응을 보였으나, 진행하는 양측 성 감각신경성 난청과 고용량의 스테로이드 치료에 현저하게 청력 호전을 보이고, 약물의 감량과 함께 청력 악화가 반복 되는 임상 양상을 통해 1 차성 자가면역성 감각신경성 난청으 
로 진단할 수 있었다. 이러한 환자에서 세포독성제제인 MTX 을 사용하여 질환을 관해 상태로 유지할 수 있었던 예를 경험 하였기에 문헌고찰과 함께 보고하는 바이다. 또한, 환자가 다 른 질환으로 설명할 수 없는 변동성 감각신경성 난청을 보이 는 경우에 반드시 자가면역성 감각신경성 난청을 의심하여야 하며, 스테로이드 치료에도 반응을 하지 않거나 재발하는 경 우에는 세포독성제제를 사용하여 증상을 조절해보는 방법 도 도움이 될 것으로 생각된다.

\section{ORCID}

Min-Beom Kim

https://orcid.org/0000-0001-8849-5148

Sun O Chang

\section{REFERENCES}

1) Cogan DG. Syndrome of nonsyphilitic interstitial keratitis and vestibuloauditory symptoms. Arch Ophthalmol 1945;33(2):144-9.

2) McCabe BF. Autoimmune sensorineural hearing loss. Ann Otol Rhinol Laryngol 1979;88(5 Pt 1):585-9.

3) Mijovic T, Zeitouni A, Colmegna I. Autoimmune sensorineural hearing loss: the otology-rheumatology interface. Rheumatology (Oxford) 2013;52(5):780-9.

4) Kim HN, Kim YH, Yim SB, Song SB. Autoimmune sensorineural hearing loss: report of 2 cases. Korean J Otorhinolaryngol-Head Neck Surg 1988;31(1):118-23.

5) Park SN, Yeo SW, Park YS, Suh BD. Immune-mediated sensorineural hearing loss in a patient with ankylosing spondylitis. Korean J Otorhinolaryngol-Head Neck Surg 2000;43(6):663-6.

6) Harris JP, Weisman MH, Derebery JM, Espeland MA, Gantz BJ, Gulya AJ, et al. Treatment of corticosteroid-responsive autoimmune inner ear disease with methotrexate: a randomized controlled trial. JAMA 2003;290(14):1875-83.

7) Kim HJ, Choi YG, Kim HJ, Kim KS. Autoimmune inner ear disease mimicking bilateral Ménière's disease: a case report. Res Vestib Sci 2018;17(1):28-35.

8) Vambutas A, Pathak S. AAO: autoimmune and autoinflammatory (disease) in otology: what is new in immune-mediated hearing loss. Laryngoscope Investig Otolaryngol 2016;1(5):110-5.

9) Moscicki RA, San Martin JE, Quintero CH, Rauch SD, Nadol JB $\mathrm{Jr}$, Bloch KJ. Serum antibody to inner ear proteins in patients with

progressive hearing loss. Correlation with disease activity and response to corticosteroid treatment. JAMA 1994;272(8):611-6.

10) García Berrocal JR, Ramírez-Camacho R, Arellano B, Vargas JA. Validity of the Western blot immunoassay for heat shock protein-70 in associated and isolated immunorelated inner ear disease. Laryngoscope 2002;112(2):304-9.

11) Pathak S, Hatam LJ, Bonagura V, Vambutas A. Innate immune recognition of molds and homology to the inner ear protein, cochlin, in patients with autoimmune inner ear disease. J Clin Immunol 2013; 33(7):1204-15.

12) Lee JM, Kim JY, Bok J, Kim KS, Choi JY, Kim SH. Identification of evidence for autoimmune pathology of bilateral sudden sensorineural hearing loss using proteomic analysis. Clin Immunol 2017;183:24-35.

13) Ruckenstein MJ. Autoimmune inner ear disease. Curr Opin Otolaryngol Head Neck Surg 2004;12(5):426-30.

14) Lim EJ, Kim SH, Lee SH, Lee KY, Choi JH, Nam EJ, et al. Reversible sensorineural hearing loss due to pachymeningitis associated with elevated serum MPO-ANCA. Clin Exp Otorhinolaryngol 2011;4(3): $155-8$.

15) Hughes GB, Barna BP, Kinney SE, Calabrese LH, Nalepa NJ. Clinical diagnosis of immune inner-ear disease. Laryngoscope 1988;98(3): 251-3.

16) Marsili M, Marzetti V, Lucantoni M, Lapergola G, Gattorno M, Chiarelli $\mathrm{F}$, et al. Autoimmune sensorineural hearing loss as presenting manifestation of paediatric Behcet disease responding to adalimumab: a case report. Ital J Pediatr 2016;42(1):81.

17) Niparko JK, Wang NY, Rauch SD, Russell GB, Espeland MA, Pierce JJ, et al. Serial audiometry in a clinical trial of AIED treatment. Otol Neurotol 2005;26(5):908-17.

18) Broughton SS, Meyerhoff WE, Cohen SB. Immune-mediated inner ear disease: 10-year experience. Semin Arthritis Rheum 2004;34(2): 544-8.

19) Ripoll È, Merino A, Grinyó JM, Torras J. New approaches for the treatment of lupus nephritis in the 21st century: from the laboratory to the clinic. Immunotherapy 2013;5(10):1089-101.

20) Chang KH, Burke JP, Coffey JC. Infliximab versus cyclosporine as rescue therapy in acute severe steroid-refractory ulcerative colitis: a systematic review and meta-analysis. Int J Colorectal Dis 2013;28 (3):287-93.

21) Mata-Castro N, Gavilanes-Plasencia J, Ramírez-Camacho R, GarcíaFernández A, García-Berrocal JR. Azathioprine reduces the risk of audiometric relapse in immune-mediated hearing loss. Acta Otorrinolaringol Esp 2018;69(5):260-7. 